In I9II he was appointed a member of the Irish Privy Council, which office he resigned in 1920 as a protest against the policy of Mr. Lloyd George's government towards Ireland.

Cox was a man with wide interests-literary, antiquarian and political.

An intimate friendship with Parnell, John Dillon and Redmond brought him into close contact with the inner politics of his country.

His connection with psychological medicine was not very marked beyond that which a noted physician experiences in his work as a general consultant.

He joined the Association in 1918, so that the number of his years with us was small, but he came at the zenith of his fame, and by doing so he did us some honour. Requiescat in pace! H. R. C. Rutherford.

\title{
C. B. Roscrow, L.R.C.P., L.R.C.S.Ed., L.R.F.P.S.Glas.,
}

Late Medical Superintendent, City Mental Hospital, Winson Green, Birmingham, and Ordinary Member since 1920.

We regret to record the death of Dr. Cecil Beaumont Roscrow, in a nursing home in Sutton, Surrey, on December 8, at the age of 56.

Dr. Roscrow received his medical education at Edinburgh University, and obtained the diplomas L.R.C.P., L.R.C.S.Ed., L.R.F.P.S. Glas., in 1894 . After a period of general practice in Sunderland and in London, and serving as ship surgeon, he went to the City of Birmingham Mental Hospital at Winson Green as Senior Assistant Medical Officer. At the end of eight years' service he succeeded the late Dr. E. B. Whitcomb as Medical Superintendent, and in June of last year retired on pension after twenty-three years' service, and went to live at Sutton, Surrey.

He had, for the last five or six years, suffered from diabetes, which influenced him in his decision to retire so early. A week before he died he developed a large carbuncle in the neck, which involved the spine, and despite two operations he passed away.

Dr. Roscrow was a man of strong character, well read and practised in his profession, and very conscientious. He had an intense dislike of publicity, and two years ago, when requested by his chairman to allow certain press representatives to visit and report on what the hospital was doing in regard to the treatment of general paralysis by malaria, etc., he did so with great reluctance, and only on condition that the names of the officers concerned should be omitted. It was characteristic of him, too, that when his predecessor died he made no effort to succeed him.

He continued the Winson Green atmosphere of homeliness, and it was his proud boast that he knew each of his 800 patients by name. He had a ready wit, and this carried him through very often when dealing with an "awkward" patient. He discouraged the display of keys by the staff (key-chains were anathema), and tried always to have the doors of the club wards open at all times of the day. He increased very much the amount of liberty given to patients, and it is the rule now, rather than the exception, that chronic patients should have a day out with their relatives every month. For those who had no friends, or whose friends lived too far away, he organized weekly picnics for the women and weekly fishing parties for the men.

He was strict in the supervision of his staff (especially if patients were concerned), but he had the rare and inestimable gift of being able to turn a blind eye to many little delinquencies when he judged that was the better course. As a result he was loved and very highly respected by his staff and by the patients, who felt they had one they could confide in. He was never very keen on games (although earlier he had played in the hospital cricket team), but he loved to study astronomy, geology and architecture. Many of his old colleagues will remember his " two in the morning " lectures on the heavens. Although he had travelled abroad a good deal, he became interested, after the war, in the various architectural features of this country, and he motored all over England in his search for architectural knowledge. At Winson Green he greatly increased the practice of sending out patients on trial with a money allowance, and the visiting by the After-Care Visitor of those who desired it. He made Winson Green one of the earliest of mental 
hospitals to introduce the "improved breakfast," and although he was a keen economist, he never attempted to cut down food, either in quantity or in quality. Other improvements, such as cinema, mechanical spreaders, mixers and so on, were added as soon as brought to his notice.

He was Clinical Lecturer in Mental Diseases in the University of Birmingham. Last year he was photographed with nearly $70 \%$ of his nursing staff, all of whom had gained the certificate of the Royal Medico-Psychological Association.

Dr. Roscrow never married, and he used to quote the late Lord Kitchener in support of his contention that the married man's interest in his work was sub ordinate to his interest in his home. At any rate he himself made his hospita his whole interest, and it is extremely sad that one who so thoroughly deserved a well-earned retirement should have been so soon cut off.

When he retired last June he was the recipient of many gifts from committee, staff and patients, and at his funeral at Sutton on December ro many representatives from the hospital went to pay a last tribute to his memory.

ERnest SHand.

\section{NOTICES BY THE REGISTRAR.}

Final Examination Results for the Nurging Certificate, November, ig26. List of Successful Candidates.

Those marked * are " with distinction."

Mental Nursing.

Berkshire.-Ellen Louisa Prendergast, Dorothy Jewell, Eileen Kathleen Gladys Lines, Annie Kirk, Grace Michael Dobson.

Cheshire, Chester.-Thomas Mellor Hooson.

Cheshire, Macclesfield.-Florence Hopkins, Hilda Jones, Kathleen Hughes, James Leslie Leighton.

Cornwall. - Muriel Soloman, *F. Higginson, Clarinda Bertolucci.

Derbyshire.-Audrey Shawcroft, Bertha Harriet Widdowson, Winifred Lucy

Goldsmith, Walter Hall, Charles Frederick Victor Low, Douglas Walters.

Devonshire.-William George Bearne.

Dorset.-Sarah Jane Daisy Carter, Florence Mary Lucas, Frank Robinson, George Goodman, Ethel Florence Swatman.

Essex, Brentwood.-*Charles Arthur Annereau, Henry Louis Jackson, George

Henry Mallinson, George Baden Perrior, Kathleen Janet T. Hewitson, Theresa

Ballantyne, May Annie Pegg, Madeline Irene Norton Harvey, Blanche Frances

Solomon, Zoe Phillips, Florence Mary Sharman, Elsie Mabel Walker, Rose

Lilian Elizabeth Cook, Gertrude Dorothy Bavin.

Essex, Severalls.- Elsie Christian Eary, Anna Mary Jones, John Robert

Crompton, Thomas William Collins, Arthur John Woolley.

Hampshire, Knowle.-Winifred Matilda Warder, Ethel Florence Josephine

Blake, Irene Iris Baker, William Stanley Lucas Matson.

Hampshire, Park Prewett.-William James Cottrell, William John Startup,

David James Locke, Arthur William Fryer, William Evans Tucker, Alice Winifred

Heron, May Anderson, *Lilian Snowdon.

Isle of Wight.-Alfred Thomas Symons, Michael Nolan.

Kent, Chartham.-Leslie Halsey, Annie Hammond, Ethel Gertrude Howell, Agnes Roach, Elsie Winifred Goodban.

Kent, Maidstone.-James Miles, Percy Leonard Jarrett.

Lancashire, Whittingham.-Edward Parkinson, Joseph Woodcock, Margaret

Halsall, Eleanor Parkinson.

Lancashire, Winwick.-Edward Thomas Jones, Percy West.

Lincolnshire, Bracebridge.-Ivy K. Howman, Elsie Toyne, James Bell.

London, Banstead.-Elsie Standing Day, Ivy Florence May Hulford, Doris Nellie

Phillips, Dorothy Gladys Nellie White, Elizabeth Annie Christian, James John Weatherley, Reginald Charles Procter, John Skeffington House, Charles Alfred Hyder.

London, Bexley.-Rose Preston, Rosina Green, Kathleen Riley, James Robert Charles Funnell, Hugh Hardy, Edward Walter Fredk. Mason, Frederick Thomas 